\title{
The Sun Grant Initiative-A New Day for Agriculture
}

\author{
Kevin D. Kephart \\ South Dakota Agricultural Experiment Station, South Dakota State University, Brookings, SD \\ Corinne J. Rutzke, Norman R. Scott, and Larry P. Walker \\ Department of Biological and Environmental Engineering, Cornell University, Ithaca, NY
}

\begin{abstract}
Summary. The Sun Grant Initiative is a new Act of Congress (Sec. 9011 of Title IX of the Farm Security and Rural Investment Act) that reflects a new vision for the future in agriculture. The Sun Grant Initiative is driven by a national consortium of land grant universities, in coordination with the U.S. Department of Agriculture and the U.S. Department of Energy. The mission of the Sun Grant Initiative is to 1) enhance national energy security through development, distribution, and implementation of biobased energy technologies; 2) promote diversification and environmental sustainability of America's agriculture through land-grant based research, extension, and education programs in renewable energy and biobased products; and 3) promote opportunities for biobased economic diversification in rural communities. Bioenergy produced on American farms represents an opportunity to both reduce dependence on imported oil and provide a significant source of income to American farmers.
\end{abstract}

\section{Background}

The U.S. economy has grown rapidly during the Industrial and Information Ages, time periods characterized by tremendous expansion in manufacturing industries and by population migration from rural communities to urban centers. Expansion occurred in agriculture as well, as farm size increased and farm numbers declined. In essence, American business industrialized and agriculture became mechanized during the 20th century. These changes were made possible by abundant access to inexpensive fossil-based energy sources in the form of coal and petroleum and to numerous hydroelectric projects in mountainous sections of the country and on major waterways such as the Missouri, Tennessee, and Columbia rivers.

\section{Energy security}

Readily accessible domestic sources of petroleum have waned over the years, forcing the U.S. to steadily increase its reliance on imported oil. The proportion of imported oil increased from about $30 \%$ of domestic consumption in 1970 to about 56\% in 2000 (National Energy Policy Development Group, 2001). This trend has raised concerns about the nation's energy security. Much of our imported oil originates from nations with unstable or allegedly repressive governments.

The United States experienced two energy crises in the same 30 -year period. The crisis of 1973 resulted from an embargo imposed by oil exporting nations. The crisis of 2000-01 was mainly caused by an aging infrastructure that had difficulty delivering electricity, natural gas, and transportation fuels to points of demand during a time of industry deregulation. Aripple effect resulted in rolling blackouts and price inflation for natural gas, synthetic fertilizers, and transportation fuels. Retail prices for gasoline and natural gas hit record levels, two to four times higher than 1 year earlier. Evidence that world oil supplies will become even more limited in the coming decades suggests that alternative sources of energy must be developed as soon as possible. Bioenergy produced on American farms represents an opportunity to both reduce dependence on imported oil and provide a significant source of income to American farmers (Biomass Research and Development Technical Advisory Committee, 2002).

\section{Rural economic development}

Farmers experienced economic stress throughout the 1990s that continues today, partly because of excessive production of core commodities. Hardship has flowed throughout rural America, and a devastating exodus to urban centers has resulted. Viable alternatives and diversity are needed in agriculture to bolster the nation's independent farm families and to meet growing concerns about energy access, costs, and security. Income from a form of alternative agriculture is sorely needed on the nation's farms.

\section{Environmental sustainability}

Arelated matter is the environmental impact of ever-increasing use of fossil-based industries in the U.S. One component in addressing the nation's energy concerns is an increased use of renewable energy. Although hydroelectric power is one form of renewable energy that has been successfully implemented, it has associated environmental consequences, and there is growing pressure to reduce dependence on this energy source. This is particularly evident in the Columbia and Snake river systems. Other major renewable resources of future interest include biomass, wind, solar, and geothermal sources. All of these elevate the role of agriculture and rural communities in the nation's energy production scene.

\section{Transition to a Biobased Economy}

Transportation fuels and electrical power are not the only products of imported oil. Plastics, synthetic fibers, lubricants, solvents, paints, and numerous other common products depend on petroleum as a feedstock. In the future, agriculture will produce biobased feedstocks for manufacture of these products and many other nonfood items. Agriculture will also be integral to manufacturing pharmaceuticals, cosmetics, building materials, biocatalysts, and numerous other biobased products (Eaglesham et al., 2000).

This biobased shift in the economy will reduce our reliance on petroleum-based products. It will further energize agriculture, as transportation logistics and infrastructure will necessitate the locating of many biobased industries in rural communities. The biobased economy will revitalize rural America.

Clearly, in the 21 st century agriculture stands ready to play an important role in providing power, fuels, and biobased products for America. As they are components of American agriculture, land-grant universities have an opportunity to enhance their service to the public.

\section{Land Grant Universities and the Sun Grant Initiative}

Since their establishment in 1862, the land grants have embraced their role as institutions of higher education. In 1887, the Hatch Act created the state agricultural experiment stations, providing a solid base of modern science for land-grant educational programs. In 1890, public colleges with predominantly African American students were given land-grant status. In 1914, the Smith-Lever Act established the Cooperative Extension Service, bringing the land-grant mission to every county of the nation. In 1994, colleges with predominantly Native American enrollments were given land-grant status.

Today, land-grant universities serve agriculture by implementing research, extension, and educational outreach in the countryside and its communities in programs that financially benefit agricultural producers and consumers, assist families in rural and urban settings to elevate their quality of life, and conserve and wisely use natural resources. Land-grant universities have a proven record of accomplishment in objective research and commitment to agriculture, rural families, and public service. Because of the contributions they have already made in science, service, and education, landgrant universities are positioned to become proactively involved in creating the biobased economy of the twenty-first century.

The Sun Grant Initiative will create a network of land-grant universities whose responsibilities will be broadened to revitalize rural communities; enhance the nation's energy security; and improve our soil, water, and air resources. The primary challenges the 
Sun Grant Initiative addresses include the following.

- Development of biobased industries that coexist with and complement petroleum based industries.

- Development of biobased industries that improve the environment and protect air, water, soil, and other natural resources.

- Development of biobased industries that diversify American agriculture and complement the nation's food production.

- Development of biobased industries that provide opportunities for the growth and prosperity of rural America.

Turning these challenges into opportunities benefits not only agriculture and rural America but also will create economic opportunities for other sectors of the U.S. economy through expansion of high-tech companies and jobs. Through the Sun Grant Initiative, the U.S. will not only produce biomass feedstocks, it will also lead the world in the technologies and the intellectual property that makes this transition to a biobased economy possible.

\section{Mission}

The mission of the Sun Grant Initiative is to do the following.

- Enhance national energy security through development, distribution, and implementation of biobased energy technologies.
- Promote diversification and environmental sustainability of America's agriculture through land-grant based research, extension, and education programs in renewable energy and biobased products.

- Promote opportunities for biobased economic diversification in rural communities.

A network of five land-grant universities serving as regional Sun Grant centers has been formed. They include South Dakota State University, Oklahoma State University, the University of Tennessee-Knoxville, Cornell University, and Oregon State University. The Center at South Dakota State University, where the Sun Grant concept originated, will serve as the National Lead Sun Grant Center. The regional centers will implement research, extension, and educational programs on agriculture-based renewable energy technologies and biobased industries located in rural communities.

Under the plan, centers will receive base federal funding to establish them as leading research, extension, and higher education institutions for the biobased economy. The centers will provide collaboration with and facilitation of ongoing and proposed federally funded research, extension, and education programs in their respective regions. These programs will embrace the multi-state, multi-function, multi-disciplinary integrated approach that is at the heart of the land-grant method of addressing problems.

\section{Current Status}

The Sun Grant Initiative Act was authorized by Congress in January 2004. With this authorization, Sec. 9011 amends Title IX of the Farm Security and Rural Investment Act of 2002 (7 U.S.C. 8101 et seq.). However, being authorized is just the first step. At this writing, Congress must still vote on appropriations before funding can be made available for the Sun Grant programs. The national Sun Grant Initiative is working with key congressional leadership to secure the appropriation to move this initiative forward. Several avenues are currently being pursued to secure funding.

\section{Literature Cited}

Biomass Research and Development Technical Advisory Committee. 2002. Roadmap for biomass technologies in the United States. http://www. bioproducts-bioenergy.gov/pdfs/FinalBiomassRoadmap.pdf.

Eaglesham, A., W.F. Brown, and R.W.F. Hardy (eds.). 2000. The biobased economy of the twenty-first century: Agriculture expanding into health, energy, chemicals, and materials. Natl. Agr. Biotechnol. Council Rpt. 12.

National Energy Policy Development Group. 2001. Reliable, affordable, and environmentally Sound energy for America's future. D. Cheney et al. Report from the national Energy Policy Development Group to the President of the United States. 